\title{
Does Customer Satisfaction Lead to Customer Trust, Loyalty and Repurchase Intention of Local Store Brands? The Case of Gauteng Province of South Africa
}

Richard Chinomona

University of the Witwatersrand, School of Economics and Business Sciences, South Africa

Dorah Dubihlela

Vaal University of Technology, South Africa

\section{Doi:10.5901/mjss.2014.v5n9p23}

\begin{abstract}
Notwithstanding the increasing researches on consumer behaviour, there is a dearth of studies that have investigated the influence of customer satisfaction on customer trust, loyalty and repurchase intention in the African retailing context. Therefore, using a data set of 151 from retailers in Gauteng Province of South Africa, this study examines these relationships. All the posited five hypotheses are supported. The results indicate that the relationship between customer satisfaction and their trust, customer satisfaction and their loyalty, customer trust and their loyalty, customer loyalty and their repurchase intention and customer trust and their repurchase intention are positive in a significant way. The research paper discusses both academic and managerial implications of the results and future research directions are suggested.
\end{abstract}

Keywords: Customer satisfaction; Customer trust; Customer loyalty; Customer repurchase intention; South Africa

\section{Introduction}

The importance of customers in a business cannot be overemphasised owing to their impact on the business sales and profitability. Continuous repurchase behaviour by consumers results in higher profit margins, competitive advantage and faster business growth (Singh \& Khan, 2012; Farquahar, 2003). Globalisation, competition and innovativeness are the major factors that have initiated research in the area of customer repurchase intention (Mauro \& Forster, 2008). Studies on factors that cause repurchase behaviour and its antecedents among consumers in today's business are plenty (Volkova, 2008:1; Arnold, Palmatier, Grewal \& Sharma, 2009; Villanueve \& Hanssens, 2007; Rust \& Chung, 2006; Seiders, Voss, Grewal, \& Godfrey, 2005). There is a growing recognition that customers have a life cycle; thus should be acquired, retained, and climb a value ladder from first time customers to partner status (Ang \& Buttle, 2006).

An inquiry on the customer repurchase behaviour is not new. Significant research on the subject has been done with different research focus. This includes investigating factors that lead to repurchase (Hellier, Geursen, Carr \& Rickard, 2002), customer repurchase and shareholder value (Ang \& Buttle, 2006) and customer repurchase behaviour and business profitability (Shi, Shi, Chan \& Wang, 2009; Farquhar, 2003). All these studies point a general consensus that customer repurchase intention can yield several economic advantages (Buttle, 2004). Since customers are key predecessors for sales, business' growth and profitability (Owusuah, 2012; Rust \& Chung, 2006; Thompson, 2005), investing in the selection of appropriate strategies remains key in ensuring their re-purchase behaviour. Previous studies have left a gap on the influence of customer satisfaction on both trust, and loyalty as mediator variables with the end result of causing a repurchase by customers. In cases where studies have concentrated on the impact of customer trust on customer loyalty, contradicting result shave been found. Ok et al. (2005) noted trust to have no significant impact on customer loyalty using community services data. Contrary to this, Kim and Han (2008) found that trust has an impact on customer loyalty using data from restaurant customers.

In plight of the above research gaps and contradicting research findings, the explicit significance of the study is to examine the contributory influence of customer satisfaction on customer loyalty and trust, the influence of customer trust on loyalty and the influence of customer loyalty and trust on the consumers' intention to continue purchasing from the same retailer in South Africa. The article takes the consumer satisfaction to be the predictor variable which influences both the consumer loyalty and consumer trust. In addition, the paper seeks to contribute new body knowledge to the existing retail businesses in a dual economy like South Africa. 
The remainder of this paper provides background literature on the research variables; repurchase intention, customer satisfaction, customer trust and customer loyalty and gives a brief overview of the retail industry in South Africa before developing a conceptual research model and the research hypotheses. The study also provides the research methodology, analyse data and present results. Finally, results are discussed, implications provided and limitations and future research directions highlighted.

\section{Literature Review}

The economic characteristics of the end-consumer are crucial to a retailer. This prompts the need to consistently carry research to remain relevant, make better business decision and increase business profitability (Ramageri \& Desai, 2013). Retailing is a type of a business approach which deals with supplying goods to the final consumer for personal or household consumption and rendering services incidental to the sale of such goods (Dinlers0z, 2004). The retailers' knowledge of consumer behaviour is useful in retaining the already existing customers (Wagner-Tsukamoto \& Tadajewski, 2006). From the consumers' point of view, many factors converge to gain satisfaction, trust and loyalty to a retailer in order to continue the relationship.

\subsection{Retailing industry in South Africa and local Store brands}

The retail industry in South Africa is classified under the tertiary sector and forms part of the major trade division which includes wholesale and retail, repair of motor vehicles, motor cycles, personal and household goods and hotels and restaurants (Aye, Balcilar, Gupta \& Majumdar, 2013). The retail industry drives the performance of the trade sub-sector and contributes about 5.7\% of total GDP also being the top in the country's share of employed labour force (Aye et al., 2013:1). In South African, retailing is composed of two different sectors: the informal sector (hawkers, small stands, and spazas), and the formal sector.

Retail businesses in South Africa are developing into a dynamic industry being driven by technology changes, a shift in consumer behaviour, intensified competitive forces and globalization (Westhuizen \& Kok, 2006) with the future challenge being growth (Wilson 2003). As consumers become affluent, they begin to try various alternatives of trusted brands. In South Africa, lower income groups residing in the townships frequently shop at local 'spaza' outlets in the informal sector. These shops tend to charge higher prices due to inexistence of the economies of scale (Klemz et al., 2006) cited in (Baneke 2010:205).

Formal sector retailers follow an oligopoly scenario and are highly dominated by private label brands. Lower income groups are also the most common purchasers of private label brands since they are affordable compared to other brands. Major retail industry players in South Africa include Edcon Pty (Ltd) for clothing footwear and textile, Pick n Pay Holdings Ltd, Shoprite Holdings Ltd, Spar Group Ltd, Woolworths Holdings Ltd and Massmart Holdings Ltd (Gauteng Quarterly Bulletin, 2012). In the 2012 Global Powers of Retailing report 5, the country's top five retailers were ranked in the global top 250 retailers. Shoprite was ranked 92nd in the retail sales rank, Massmart (126th), Pick n Pay ranked (133rd), Spar (179th) and Woolworths (222nd) (Gauteng Quarterly Bulletin, 2012).

\subsection{Re-purchase intention}

Consumer buying behaviour can be understood in two stages, thus encouraging people to purchase and enhancing them to repurchase (Zhang, Fang, Wei, Ramsey, McCole \& Chen, 2011). Repurchase intention refers to the consumer's willingness to buy for a long time from the same company (Gounaris, Dimitriadis \& Stathakopoulos, 2010). It can also refer to the individual's judgment about buying again a designated service from the same company (Lacey \& Morgan, 2009). Repurchase intention is defined by Hellier, Geursen, Carr, and Rickard (2003) as the individual's decision about repeatedly buying the product/service from the same company, taking into account his/her current situation and circumstances. First-time purchase is often used as a predictive measure of repurchase behaviour. The decision to repurchase represents the customer's decision to engage in continuous consumption of the product. Seiders, Voss, Grewal and Godfrey (2005) and Yi and La (2004) confirm a positive relationship between repurchase intentions and customer satisfaction. According to Kaveh (2011) this relationship simplifies the matter because in real world, many factors converge in order to make a decision to repurchase.

Increased costs of getting new customers are rising. Marketing managers now rely on repurchase intentions to predict sales and increase profits in a variety of marketing activities (Pérez, Sánchez, Abad, Carrillo, \& Fernández, 2007), and demand forecasting for existing products. Similarly, academic researchers frequently use purchase intention as a 
proxy for repurchase behaviour (Morwitz, Steckel \& Gupta, 2007). Perhaps most importantly, repurchase intentions are the most widely used indicator of customer satisfaction, trust and loyalty in firms' behaviour.

\subsection{Customer satisfaction}

Customer satisfaction involves features or characteristics that can satisfy the need or want of a customer (Bagram \& Khan, 2012). According to Cengiz (2010) it is a post consumption experience which compares perceived quality with expected quality, thus a comparative behaviour between inputs beforehand and after consumption. Customer satisfaction is an abstract concept where the actual satisfaction varies from individuals and products depending on a number of variables which include service quality and the individual expectations (Cengez, 2010). Low quality service, which does not reach the customers' expectations, leads to consumer dissatisfaction (Bagram \& Khan, 2012).

According to Hanif, Hafeez and Riaz (2010) high level of satisfaction is established when the brand fulfils the needs of customers far more than the competing brands. Consumer satisfaction is also seen as a key performance indicator within a business (Adolphson, Eklöf \& Parmler, 2012). There is evidence that prioritising customer satisfaction is essential to improve the business' profitability (Cengiz, 2010; Zhang \& Pan, 2009; Anderson, Furnell, \& Rust, 1997) the two being positively related. Businesses therefore now elevate the role of customers to that of stakeholders as an exceptional business strategy.

Customer satisfaction in a business is fundamental. Unsatisfied consumers are also quick to switch from the brand which fails to fulfil basic requirements. Furthermore, Morgan (2009) noted that a dissatisfied customer may relate a bad experience to 5 to 15 other people, eroding potential patronage of the service provider. Satisfaction is an important precursor in promoting customer repurchase behaviour (Tsai \& Haung, 2007), as it can affect a buyer's decision to continue a relationship with the organisation (Ndubisi, Malhotra \& Chan 2009).

\subsection{Customer Trust}

Ganiyu, Uche and Elizabeth (2012) concur that customer satisfaction can lead to trust, then a repurchase decision. Trust is when a customer highly believes in a specific product or service. According to Eid (2011) trust is a set of beliefs held by a consumer concerning certain characteristics of the supplier as well as the future behaviour of such a supplier. It is a level of confidence that one party has on another party that they would behave as expected. Trust can influence the willingness to repurchase from a particular company (Jarvenpaa, Tractinsky, \& Vitale, 2000). According to Ha and Akamavi (2009) trust based on prior affective experience plays a crucial role in facilitating consumers' further repurchase intentions.

Moorman et al (1993) cited in La and Choi (2012) viewed trust using two approaches. The first approach was as a belief, confidence or expectation about another party's worthiness that results from expertise or reliability. The other views trust as one's reliance upon another due to their vulnerability or uncertainty. Pertaining beliefs, numerous researchers have emerged and they include (Doney \& Cannon, 1997) who suggest two types of beliefs; honesty and benevolence, McKnight and Chervany (2001-2002) who believed that the trustee possesses features that would benefit the trustor and Ring \& Van de Ven (1994) who perceived trust as some perceptions about the ethical character.

Trust has become important in many business decisions involving uncertainty and dependency. For consumers to establish trust with the retailers, information has to be revealed by about the products. In reality some retailers promote products which may mislead consumers, negatively influencing the purchase thereby hindering consumer trust of products (Moodie, Stead, Bauld, McNeill, Angus, Hinds, Kwan, Thomas, Hasting \& O'Mara-Eves, 2012). Moreover, businesses have limitations such as the physical separation between buyers and sellers which forces retailers to be trustworthy in order to foster customer trust.

\subsection{Customer Loyalty}

Researches that suggests a strong relationship between consumer loyalty and repurchase intention is substantial (Van Vuuren, Roberts-Lombard \& Tonder 2012; Singh \& Khan, 2012; Vesel \& Zabkar, 2009; Ang \& Buttle, 2006; Thompson, 2005). Oliver (1999) defines customer loyalty as a situation where a consumer keeps purchasing the product at the same shop for a long time. It is repurchase behaviour and a commitment to re-patronize the product despite influences and marketing efforts to cause a switching behaviour and keep the relationship with a particular company in future purchases (Inamullah, 2012; Bagram \& Khan, 2012; Eid, 2011). This relationship is built on the belief that the retailer gives a better service and the desire to be with the same service provider (Yang \& Peterson, 2004; Vesel \& Zabkar, 2009). On the other 
hand, Ruyter, Moorman and Lemmink (2001) suggest switching risks and cost of training as key operators that lead to loyalty.

Yang and Peterson (2004) note the following advantages of highly loyal customers; the possibility of attracting more customers, forgive the customer service mishaps, price insensitive and being a major source of retail profits. These advantages create a reason for the operators to promote loyalty as a main operation target. At a global level, customer loyalty is generally positively related to the profitability and long-term growth of a firm (Helgesen, 2010; Bagram \& Khan, 2012). Hence the need to determine the key factors like satisfaction, high switching costs, trust and commitment that influence customer loyalty as this can be a critical asset for retailers (Vesel \& Zabkar, 2009).

\section{Theoretical Framework and Hypotheses Development}

The theoretical framework guiding the investigation is depicted in figure 1 below, adapted from Agus, Arawati, Barker, Sunita \& Kandampully, Jay (2007) and Caruana (2002). This research will study 4 variables: repurchase intention, customer satisfaction, customer trust and customer loyalty in the retail business in South Africa. In this model, customer satisfaction impacts repurchase intention indirectly via customer loyalty and consumer trust. Consumer trust can lead to customer loyalty then the intention to repurchase.

Figure 1: Conceptual Model

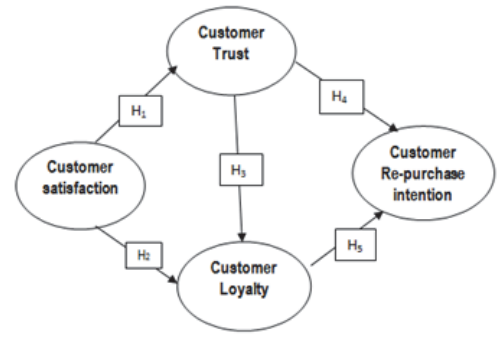

\subsection{Customer satisfaction, loyalty and trust}

The study of consumer behaviour tells that consumers want satisfaction in order to remain loyal to their retailers (Yang \& Petersen, 2004) while on the other hand, retailers are uncertain about what satisfies consumers. Due to the aggressive nature of today's business, there is need for the retailer to gain some form of differential advantages to their customers in a bid to retain them (McElheran (2013). According to research by (Ali \& Sankaran, 2010; Mattsson, 2009), customer satisfaction is the key antecedent to consumer loyalty, trust and a repurchase behaviour. The following hypotheses are therefore proposed:

$\mathrm{H}_{1}$ and $\mathrm{H}_{2}$ : Customer satisfaction influences consumer trust and loyalty

\subsection{Customer trust and customer loyalty}

The concept of customer loyalty is used in this research as the customers' positive attitude on particular brand manifested on consistent repurchase. A relationship including trust and loyalty has been appraised in various ways by different researchers, with some having taken it to be an antecedent of overall satisfaction (Ok et al., 2005). The impact of trust on customer loyalty is yet to be reconciled since researchers are coming up with different results. Ok et al. (2005) noted that trust has no significant influence on customer loyalty using community services data while Kim and Han (2008) found trust to have an influence on customer loyalty using data from restaurant customers. Since trust is a long-term orientation (Caceres \& Paparoidamis, 2007) and forward looking in nature, then logically it can be asserted that trust will have an influence on the customer loyalty in the retail sector in South Africa, hence the hypothesis:

$\mathrm{H}_{3}$ : Customer trust has a direct influence on customer loyalty

\subsection{Consumer trust and repurchase intentions}

According to Grewal, Hardesty and lyer (2004) a high level of repurchase intention will exist in a consumer with trust. 
Also, where trust exists, there is an intention to accept flaws based on positive expectations. In a market place, satisfaction which leads to customer trust has to be established between the retailer and consumer in order to ensure purchase. Also, due to uncertainties in transactions, (Gounaris, 2005) noted trust as a critical factor influencing repurchase behaviour since it stimulates a relational bond between the supplier and the customer, hence $\mathrm{H}_{4}$.

$\mathrm{H}_{4}$ : Consumer trust has a direct positive relationship with customer repurchase intentions

\subsection{Consumer loyalty and repurchase intentions}

Whereas making consumer loyal toward a company product is not an easy task (Bagram \& Khan, 2012), and no substitute for good planning or research (Thompson, 2005) this loyalty plays a pivotal role in achieving and maintaining a competitive advantage and hence a repurchase decision. According to Yang and Peterson (2004) personal bonding fortitude keep a customer over period of time despite the intensified competition among retailers as a result of new technologies, sophisticated management practices and industry consolidation. Hence the hypothesis;

$\mathrm{H}_{5}$ : Customer loyalty has a direct positive relationship with customer repurchase intentions

\section{Research Methodology}

\subsection{Sample and data collection}

The target population for the study was South African customers or clients in Gauteng who purchase at major retailers such as Checkers, Pick n Pay, Shop Rite, Spar and Game. Students from the Vaal University of Technology were recruited as research assistants to distribute and collect the questionnaires. Of the total of 170 questionnaires distributed, 151 usable questionnaires were retrieved for the final data analysis, representing a response rate of $89 \%$. To eliminate differences in response patterns due to different reference points, all respondents were prompted to answer the questionnaire with reference to their favourite store brands. Respondents were then asked to indicate their favourite retailer and then complete the entire questionnaire, guided by the research assistants.

\subsection{Measurement Instrument and Questionnaire Design}

Research scales were operationalized on the basis of previous work. Proper modifications were made in order to fit the current research context and purpose. "Customer satisfaction" measure used five-item scales adapted from Chinomona and Cheng (2013) and Sahin, Zehir and Kitapçi (2011). "Customer trust" and "customer loyalty" used a four-item scale measure adopted from Chaudhuri and Holbrook (2001). Finally, "customer repurchase intention" used three-item scale measure all adapted from Hellier, Geursen, Carr and Rickard (2003). All the measurement items were measured on a five-point Likert-type scales that was anchored by $1=$ strongly disagree to $5=$ strongly agree to express the degree of agreement.

\subsection{Respondent Profile}

The respondents were asked to report their demographic information, including gender, age, marital status and education. Out of a sample set of 151, the majority of the respondents were female (59.5\%). The median age group of the respondent was less than 30 years (55.4\%). $58 \%$ of the respondents were single. About $79.4 \%$ of the respondents had either high school (53\%) or university level of education (26.4\%) and the remainder had primary school (14.9\%) or postgraduate level of education (5.7\%).

\section{Data Analysis}

\subsection{Structural Equation Modelling Approach}

In order to statistically analyze the measurement and structural models, this study used Smart PLS software for Structural Equation Modeling (SEM) technique (Ringle, Wende \& Will 2005). In SEM, the measurement model refers to the linkages between the latent variables and their manifest variables and the structural model captures the hypothesized causal relationships among the research constructs (Chin \& Newsted, 1999). Unlike AMOS and LISREL which are covariancebased approaches, Smart PLS is a regression based technique that originates from path analysis. Smart PLS has 
emerged as a powerful approach to study causal models involving multiple constructs with multiple indicators (Chinomona \& Surujal, 2012). Smart PLS - a component-based method, has an ability to model latent constructs that are uncontaminated by measurement error under conditions of non-normality. It has the ability to handle complex predictive models in small-to-medium sample sizes. Since the current study sample size is relatively small (151) Smart PLS was found more appropriate and befitting the purpose of the current study. In this respect, Bootstrapping resampling method was used to test the statistical significance of the relationships. This procedure entailed generating 200 sub-samples of cases randomly selected, with replacement, from the original data. Below is Table 1, presenting evidence on the reliability and validity of the measurement model.

\subsection{Measurement Model}

The validity of the model was checked. With regards to convergent validity, the researchers checked if items loaded on their respective (a priori) constructs had loadings greater than 0.6. Discriminant validity was tested in line with Chin (1998) by ensuring that there were no significant inter-research variables cross-loadings. Table 1 shows that all items have loadings greater than 0.6 (i.e. ranging from 0.641 to 0.763 ), with no cross-loadings greater than 0.619 , while tstatistics derived from bootstrapping (200 resamples) suggest all loadings are significant at pb0.001. As such, this confirms that all the measurement items are acceptable measures since they converged well on their respective constructs.

Table 1: Accuracy Analysis Statistics

\begin{tabular}{|c|c|c|c|c|c|c|c|c|}
\hline \multicolumn{2}{|c|}{$\begin{array}{l}\text { Research } \\
\text { Construct }\end{array}$} & $\begin{array}{c}\text { LV Index } \\
\text { Value }\end{array}$ & $\begin{array}{l}\text { R-Squared } \\
\text { Value }\end{array}$ & $\begin{array}{c}\text { Cronbach's } \alpha \\
\text { value }\end{array}$ & $\begin{array}{l}\text { C.R. } \\
\text { Value }\end{array}$ & $\begin{array}{l}\text { AVE } \\
\text { Value }\end{array}$ & Communality & $\begin{array}{l}\text { Factor } \\
\text { Loading }\end{array}$ \\
\hline \multirow{5}{*}{ CS } & CS1 & \multirow{5}{*}{3.920} & \multirow{5}{*}{0.000} & \multirow{5}{*}{0.798} & \multirow{5}{*}{0.804} & \multirow{5}{*}{0.452} & \multirow{5}{*}{0.452} & 0.684 \\
\hline & CS2 & & & & & & & 0.695 \\
\hline & CS3 & & & & & & & 0.642 \\
\hline & CS4 & & & & & & & 0.644 \\
\hline & CS5 & & & & & & & 0.692 \\
\hline \multirow{3}{*}{ CT } & CT1 & \multirow{3}{*}{3.952} & \multirow{3}{*}{0.197} & \multirow{3}{*}{0.564} & \multirow{3}{*}{0.737} & \multirow{3}{*}{0.483} & \multirow{3}{*}{0.483} & 0.671 \\
\hline & СТ2 & & & & & & & 0.732 \\
\hline & CT3 & & & & & & & 0.681 \\
\hline \multirow{3}{*}{$C L$} & CL1 & \multirow{3}{*}{4.020} & \multirow{3}{*}{0.379} & \multirow{3}{*}{0.563} & \multirow{3}{*}{0.732} & \multirow{3}{*}{0.478} & \multirow{3}{*}{0.478} & 0.713 \\
\hline & CL2 & & & & & & & 0.631 \\
\hline & CL3 & & & & & & & 0.726 \\
\hline \multirow{3}{*}{ CRI } & CRI & \multirow{3}{*}{4.073} & \multirow{3}{*}{0.422} & \multirow{3}{*}{0.601} & \multirow{3}{*}{0.749} & \multirow{3}{*}{0.500} & \multirow{3}{*}{0.500} & 0.641 \\
\hline & CRI2 & & & & & & & 0.763 \\
\hline & CRI3 & & & & & & & 0.712 \\
\hline
\end{tabular}

Note: CS = Customer Satisfaction; CT = Customer Trust; CL = Customer Loyalty; CRI = Customer Repurchase Intention

Chin (1998) concurs that research variables should have an average variance extracted (AVE) of more than 0.4 and a composite reliability of more than 0.7 (convergent validity). Furthermore, inter-construct correlations should be less than the square-root of the AVE (discriminant validity). As shown in (Table 1), all constructs exceed these criteria, with AVE ranging from 0.452 to 0.5 and $C R$ value between 0.732 and 0.804 . Additionally, as indicated in Table 2 , the square-root of the lowest AVE is 0.672 and is greater than the highest inter-construct correlation value $(0.619)$. Therefore, these results confirm the existence of discriminant validity of the measurement used in this study.

Table 2: Correlations between Constructs

\begin{tabular}{|l|l|l|l|l|}
\hline \hline Research Constructs & CS & CT & CL & CRI \\
\hline Customer Satisfaction (CS) & 1.000 & & & \\
\hline Customer Trust (CT) & 0.444 & 1.000 & & \\
\hline Customer Loyalty (CL) & 0.542 & 0.503 & 1.000 & \\
\hline Customer Repurchase Intention (CRI) & 0.601 & 0.480 & 0.619 & 1.000 \\
\hline \hline
\end{tabular}

Note: CS = Customer Satisfaction; CT = Customer Trust; CL = Customer Loyalty; CRI = Customer Repurchase Intention 


\subsection{Path Model}

PLS further creates the path coefficients for the relationships modelled among the constructs. The significance of these coefficients was assessed using the bootstrap procedure (with 200 sub-samples) which provided the t-values for each path estimate. Figure 2 and Table 3 presents the results of the PLS analysis on the structural model together with the path estimates and t-values. Support for the study hypotheses, which are labelled on their corresponding paths in Figure 2 , could be ascertained by examining the directionality (positive or negative) of the path coefficients and the significance of the t-values. According to Chin (1998) the standardized path coefficients are expected to be at least 0.2 , and preferably greater than 0.3

Figure 2: Measurement and Structural Model Results

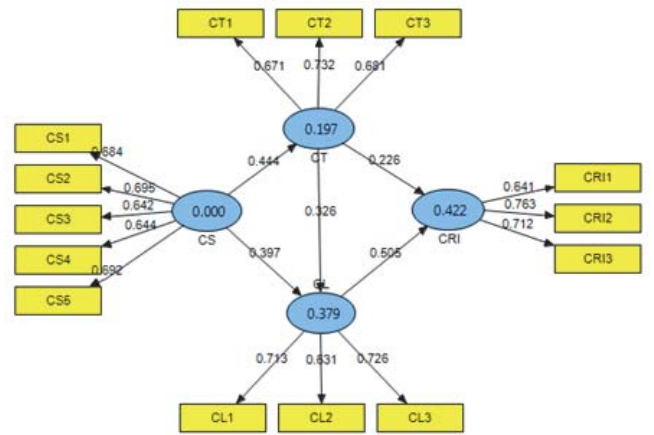

Note: CS = Customer Satisfaction; $\mathrm{CT}=$ Customer Trust; $\mathrm{CL}=$ Customer Loyalty; $\mathrm{CRI}=$ Customer Repurchase Intention

The results provide support for the proposed positive relationships between the five relationships (i.e. $\mathrm{H}_{1}, \mathrm{H}_{2}, \mathrm{H}_{3}, \mathrm{H}_{4}$ and $\mathrm{H}_{5}$ ). Figure 2 and Table 3 provide the path coefficients for $\mathrm{H}_{1}, \mathrm{H}_{2}, \mathrm{H}_{3}, \mathrm{H}_{4}$ and $\mathrm{H}_{5}$ (i.e. $0.444,0.397,0.326,0.226$ and 0.505 respectively).

Table 3: Results of Structural Equation Model Analysis

\begin{tabular}{|l|c|c|c|c|}
\hline \hline \multicolumn{1}{|c|}{ Proposed Hypothesis Relationship } & Hypothesis & $\begin{array}{c}\text { Path } \\
\text { Coefficients }\end{array}$ & $\begin{array}{c}\text { T- } \\
\text { Statistics }\end{array}$ & $\begin{array}{c}\text { Rejected I } \\
\text { Supported }\end{array}$ \\
\hline Customer Satisfaction (CS) $\rightarrow$ Customer Trust (CT) & $\mathrm{H} 1$ & 0.444 & 4.871 & Supported \\
Customer Satisfaction (CS) $\rightarrow$ Customer Loyalty (CL) & $\mathrm{H} 2$ & 0.397 & 4.106 & Supported \\
Customer Trust (CT) $\rightarrow$ Customer Loyalty (CL) & $\mathrm{H} 3$ & 0.326 & 3.443 & Supported \\
Customer Trust (CT) $\rightarrow$ Customer Repurchase Intention (CRI) & $\mathrm{H} 4$ & 0.226 & 2.300 & Supported \\
Customer Loyalty (CL) $\rightarrow$ Customer Repurchase Intention (CRI) & $\mathrm{H} 5$ & 0.505 & 5.811 & Supported \\
\hline \hline
\end{tabular}

Note: CS = Customer Satisfaction; CT = Customer Trust; CL = Customer Loyalty; CRI = Customer Repurchase Intention

Overall, $\mathrm{R}^{2}$ for $\mathrm{CT}, \mathrm{Cl}$ and $\mathrm{CRI}(0.197,0.379,0.422$ respectively) in Figure 2, indicate that the research model explains more than $19.7 \%$ of the variance in the endogenous variables. Following formulae provided by Tenenhaus, Vinzi, Chatelin \& Lauro, (2005), the global goodness-of-fit (GoF) statistic for the research model was calculated using the equation:

\section{$\mathrm{GoF}=\sqrt{\overline{\mathrm{AVE}} * \overline{\mathrm{R}^{\mathrm{B}}}}$}

The calculated global goodness of fit $(\mathrm{GoF})$ is 0.47 , which exceed the threshold of GoF $>0.36$ suggested by Wetzels, Odekerken-Schröder and van Oppen (2009). Thus, this study concludes that the research model has a good overall fit.

\section{Discussion of Results}

The results in Table 3 and Figure 2 provide support for the five (5) hypotheses $\left(H_{1}, H_{2}, H_{3}, H_{4}\right.$ and $\left.H_{5}\right)$. $H_{1}$ posited a positive relationship between customer satisfaction and customer trust. Consistent with $\mathrm{H}_{1}$, the result in Table 3 and 
Figure 2, indicates that there is a significant $(t=4.871)$ positive $(\beta=0.444)$ relationship between customer satisfaction and customer trust, therefore consistent with the prediction of $\mathrm{H}_{1} . \mathrm{H}_{2}$ showed a positive association between customer satisfaction and customer loyalty. $\mathrm{H}_{2}$, results indicated that customer satisfaction is positively associated with customer loyalty $(\beta=0.397)$ and the relationship is significant $(t=4.106)$. This is consistent with the prediction of $\mathrm{H}_{2}$ and is therefore supported. The standardized coefficient and significant levels of customer trust and customer loyalty is $(\beta=0.326$; $t=$ 3.443) is positive and significant. This is consistent with the prediction of $\mathrm{H}_{3}$ and is supported. Thus, a higher level of customer trust is associated with higher levels of customer loyalty. Furthermore, the results in Table 3 and Figure 2, are in line with $\mathrm{H}_{4}$ and support the reasoning that the higher the level of customer trust, the higher the level of repurchase intention ( $\beta=0.226 ; t=2.300$ ). Therefore, $\mathrm{H}_{4}$ is supported. Finally, the results depicted in Table 3 and Figure 2 are also consistent with $\mathrm{H}_{5}$ and support the proposition that the more customers are loyal with a retailer the more they are likely to repurchase from the same retailer $(\beta=0.505, t=5.811)$.

\subsection{Conclusion}

The purpose of this study was to investigate the influence of customer satisfaction, on customer's trust and customer loyalty in causing customer repurchase behaviour. In particular, five hypotheses were postulated. To test these hypotheses, data were collected from Gauteng Province in South Africa. The empirical result supported all the five posited research hypotheses significantly. Important in the study is that customer satisfaction has influence on customer loyalty and customer trust in achieving consumer repurchase intention. This implies that customer satisfaction is the main factor on repurchase intention.

\subsection{Implications of the study}

Despite the increased recognition of customer satisfaction as a critical aspect in today's competitive business environment, present literature provides empirical evidence suggesting that customer satisfaction, customer trust, and customer loyalty lead to a repurchase intention. This study, nevertheless, was set to depart from this traditional theory in arguing that customer satisfaction causes a repurchase intention through customer trust and loyalty. Furthermore, customer satisfaction can impact on customer trust, then customer loyalty, leading to a repurchase intention. Attempt was made to investigate the causal relationships between these constructs in the retail industry. In addition to that, the current study investigate this contentious issues in an often most neglected research context - the African setting. Therefore, the findings of this empirical study are expected to provide fruitful new insights and implications to both academicians and retail business industries across the globe.

On the academic arena, this study significantly contributes to the repurchase behaviour and the literature in the retail industry by exploring the impact of customer satisfaction on customer's trust and customer loyalty with the end outcome of achieving repurchase behaviour in the retail industry in the African context. In particular, the current study findings provide tentative support to the proposition that customer satisfaction, through customer trust and customer loyalty should be recognized as antecedents that precipitate an intention to repurchase in the retail industry.

On the business practitioners' side, important influential role of customer's satisfaction and their trust and loyalty and consequently their repurchase intention in an African context are highlighted. Therefore, this study implies that retailers seeking to find ways to increase their sales through customer repurchase behaviour should start to consider not only the relationship of customer satisfaction, customer trust, customer loyalty but rather a behaviour that is precipitated by the satisfaction gained by the customers, then develops to trust and loyalty before it manifest itself in the form of loyalty to the retailer.

\subsection{Limitations and Future Research}

While this study makes substantial contributions to research knowledge and practice, it had some limitations, therefore suggesting some future research avenues. First, the data was gathered from Gauteng Province of South Africa and the sample size of 151 is relatively small. Conceivably, with the availability of resources, the results would be more informative if the sample size is large and data gathered from all the nine provinces in the country. Second, possibly future studies should consider extending this research to other African countries such as Swaziland for results comparison. Future studies can also extend the current study by studying the relationships in the current conceptual model in other sectors of the economy with different characteristics from the retail industry. Focus can be placed on specific commodity groups like food, clothing, motor sector etc. This will greatly contribute new knowledge to the existing 
body of consumer repurchase behaviour in the African setting.

\section{References}

Adolphson, J., Eklöf, J. \& Parmler, J. 2012. Customer satisfaction is a key performance indicator in Bank management. Stockholm: Stockholm University.

Ali, P. \& Sankaran, S. 2010. Online shopping, customes' satisfaction and loyalty in Norway. MBA dissertation. Blekinge: Tekniska Hogslola BTH.

Anderson, E.W., Furnell, C. \& Rust, R.T. 1997. Customer satisfaction, productivity and profitability: Differences between goods and services. Nashville: The University of Michigan.

Ang, L. \& Buttle, F. 2006. Customer retention management process: A quantitative study. European Journal of marketing. 40 (1/2), 83-99

Arnold, T.J., Palmatier, R.W., Grewal, D. \& Sharma, A. 2009. Understanding retail managers' role in the sale of products and services. Journal of retailing 85 (2), 129-144.

Aye, G.C., Balcilar, M., Gupta, R. \& Majumdar, A. 2013. Forecasting aggregate retail sales: The case of South Africa. Pretoria: University of Pretoria.

Bagram, M.M.M. \& Khan, S. 2012. Attaining consumer loyalty. The role of consumer attitude and consumer behaviour. International Review of Management and Business Research. 1 (1), 1-8.

Baneke, J. 2010. Consumer perceptions of private label brands within the retail grocery sector of South Africa. African Journal of Business Management. 4 (2), 203-220.

Buttle, F. 2004. Customer relationship management: Concepts and tools. Oxford: Elsevier.

Caceres, R.C. \& Paparoidamis, N.G. 2007. Service quality, relationship satisfaction, trust, commitment and business-to-business loyalty. European Journal of Marketing, 14(7/8), 836-67.

Caruana, A. 2002. Service loyalty: The effects of service quality and the mediating role of consumer satisfaction. European Journal of Marketing. 36 (7/8), 811-828.

Cengiz, E. 2010. Measuring customer satisfaction: must or not. Journal of Naval Science and Engineering. 6 (2), 76-88.

Chaudhuri A. \& Holbrook M.B. 2001. The chain of effects from brand trust and brand affect to brand performance: The role of brand loyalty. Joumal of Marketing . 65 (April), 81-93.

Chin, W.W. 1998. Issues and opinion on structural equation modelling. MIS Quarterly. 22 (1), 7-16.

Chin, W.W. \& Newsted, P.R. 1999. Structural equation modeling analysis with small samples using partial least squares. In Rick Hoyle (ed). Statistical Strategies for Small Sample Research. Thousand Oaks, CA: Sage.

Chinomona, R. \& Cheng, J.M.S. 2013. Distribution Channel Relational Cohesion Exchange Model: A small to medium Enterprise Manufacturer's perspective. Journal of Business Management. 51 (2), 256-275.

Chinomona, R \& Surujlal, J. 2012. The influence of student internship work experience on their self-improvement and professionalism in Sport Management. African Journal for Physical, Health Education, Recreation and Dance (AJPHERD). 18: 4(2), 885-899.

Dinlers0z, E.M. 2004. Firm organisation and the structure of retail markets. Journal of Economics and Management Stratergy 13 (2), 207-240.

Doney, P. \& J. Cannon. 1997. An Examination of the Nature of Trust in Buyer-Seller Relationships. Journal of Marketing. 61, 35-51.

Eid, M.I. 2011. Determinants of e-commerce customer satisfaction, trust and loyalty in Saudi Arabia. Journal of electronic commerce Research. 12 (1) 78-93.

Farquhar, J.D. 2003. Customer retention in retail financial services: an employee pespetive. International Journal of Bank Marketing. 22 (2), 86-99.

Ganiyu, A.R., Uche I.I. \& Elizabeth, A. 2012. Is customer satisfaction an indicator of customer loyalty. Australian Journal of Business and Management Research 2 (70), 14-28.

Gauteng Quarterly Bulletin, 2012. The Retail Industry on the Rise in South Africa. Pretoria: Government Printers.

Gerpott. T. J., Rams, W. \& Schindler, A. 2001. Customer retention, loyalty and satisfaction in the German mobile cellular telecommunications. Market Telecommunications policy 25, 249-269.

Gounaris, S.P. 2005. Trust and commitment influenceson customer retention: Insights from business to business services. Journal of Business research 58 (2), 126-140.

Gounaris S,. Dimitriadis S. \& Stathakopoulos, V. 2010. An Examination of the Effects of Service Quality and Satisfaction on Customers' Behavioural Intentions in E-Shopping. Journal of Service Marketing. 24(2), 142-156.

Grewal, D., Hardesty, D.M. \& Iyer, G.R. 2004. The effects of buyer identification and purchase timing on customers perceptions of trust, price fairness and repurchase intention. Journal of interactive marketing 8(4), 87-100.

Ha, H.Y. \& Akamavi, R.K. 2009. Does trust really matter in electronic shopping? A comparison study of Korean, Taiwanese and United Kingdom consumers. Seoul Journal of Business. 15 (1), 91-119.

Hallowell, R. 1996. The relationship of customer satisfaction, customer loyalty and profitability and empirical study. Boston: Harvard Business School.

Hanif, M., Hafeez, S. \& Riaz, A. 2010. Factors affecting customer satisfaction. International Research Journal of Finance and Economics 60(2010), 44-52.

Hellier. P.K., Geursen, G.M., Carr, R.A. \& Rickard, J.A. 2003. Customer repurchase intentions: a general structural equation model. European Journal of Marketing. 37 (11), 1762-1800.

Inamullah, K. 2012. Impact of customer satisfaction and customer retention and customer loyalty. International Journal of Scientific and Technology Research 1 (2), 106-110.

Jarvenpaa, S. L., Tractinsky, J. \& Vitale, M. 2000. Consumer trust in an internet store. Information Technology and Management, 1(1\&2), 45-71.

Karadeniz, M. 2009. The importance of retail site selection in marketing management and hypothetical approaches used in site selection. Journal of Naval Science and Engineering 5(3) 79-90.

Kaveh, M. 2011. Role of trust in explaining repurchase intentions. African Journal of Business Management. 6 (14) 5014-5025.

Khan, S. \& Afsheen, S. 2012. Determinants of customer satisfaction in Telecom industry. A study of telecom industry Peshawar KPK Pakistan. Journal of Basic and Applied Scientific Research 2 (12), 12833-12840.

Kim, W. \& Han, H. Determinants of restaurant customers" loyalty intentions: a mediating effect of relationship quality. Journal of Quality Assurance in Hospitality and Tourism. 9(3), 219-39.

La, S. \& Choi, B. 2012. The role of customer affection and trust in ?? loyalty building after service failure recovery. The Service Industry Journal 32 (105-125). Li-Ting, H., Jun-Der, L. \& Cheng-Kiang, F. 2007. Factors affecting consumer loyalty to application service providers in different levels of relationship. 
Tauyuan: Chang-Gund University

MacKnight, D.H., \& Chervany, N.L. 2001-2002. What trust means in e-commerce customer relationships: an interdisciplinary conceptual typology. International Journal of Electronic Commerce 6 (2) 35-59.

Mattson, K. 2009. Customer satisfaction in the retail market. Vaasan Ammattikorkeakoulu: University of Applied Sciences.

Mauro, F. \& Forster, K. 2008. Globalisation and the competitiveness of the Euro area. European Centralbank: Frankfurt an main.

McElheran, K. 2013. Do market leaders lead in business process innovations? The case (s) of e-bussiness adoption. Harvard: Harvard business school.

Moodie, C. Stead, M. Bauld, L. McNeill, A., Angus, K.Hinds, K., Kwan, I. Thomas, J., Hasting, G. \& O’Mara-Eves, A. 2012. Plain Tobacco Packaging: A Systematic Review. Stirling: University of Stirling.

Morgan, R.L. 2009. Calming upset customers: Stay in control .... in any situation. $4^{\text {th }}$ ed. San Jose: Axzo Press

Monvitz, V.G., Steckel, J.H. \& Gupta, A. 2007. "When do purchase intentions predict sales?" International Journal of Forecasting. 23 (3), $347-364$.

Ndubisi, N.O., Malhotra, N.K. \& Chan, K.W. 2009. 'Relationship marketing, customer satisfaction and loyalty: a theoretical and empirical analysis from an Asian perspective', Journal of International Consumer Marketing, 21(1): 5.

Nitzan, I \& Libai, B 2011. Social effects of customer retention. Journal of Marketing 1-63.

Ok, C., Back, K. \& Shanklin, C.W. 2005. Modeling roles of service recovery strategy: a relationship-focused view. Journal of Hospitality \& Tourism Research, 29(4), 484-507.

Oliver, R.L. 1999. Whence consumer loyalty. Journal of marketing. 3 (Special Issue), 33-44.

Owusuah, E. 2011. Assessing the effect of customer retention: A case of Stanbic Bank Kumasi. Kumasi: Christian service University College.

Pérez, M., Sánchez, J.C.G., Abad, G. M., Carrillo, M. \& Fernández, R.S. 2007. "Effects of service quality dimensions on behavioural purchase intentions; A study in public-sector transport," Managing Service Quality, 7, (2), 134-151.

Quarterly Bulletin- Gauteng Province. 2012. The Retail Industry on the Rise in South Africa. Pretoria: Provincial treasury.

Ramageri, B.M. \& Desai, B.L. 2013. Role of data mining in retail sector. International Journal of computer science and Engineering. 5 (1) 47-50.

Ring, P.S. \& Van de Ven, A.H. 1994. Developmental process of cooperative interorganizational relationships. Academy of management review 23 (3), $393-$ 404.

Ringle, C.M, Wende, S. \& Will, A. 2005. Smart PLS 2.0 M3. Available at http://www.smartpls.de. Accessed 23/09/2013.

Rust, R.T. \& Chung, T.S. 2006. Marketing models and relationships. Marketing Science 25 (6) 560-580.

Ruyter, K., Moorman, I. \& Lemmink, J. 2001. Antecedents of commitment and trust in customer-supplier relationships in high technology market. Industrial Marketing Management 30, 271-286.

Sahin, A., Zehir, C., Kitapçı, H. 2011. The Effects of Brand Experiences, Trust and

Satisfaction on Building Brand Loyalty; An Empirical Research On Global Brands: Elsevier Ltd.

Seiders, K., Voss, G.B., Grewal, D. \& Godfrey, A.L. 2005. Do satisfied customers buy more? Examining moderating influences in a retailing context. Journal of Marketing. 69 (4), 26-43.

Shi, G., Shi, Y.K., Chan, A. \& Wang, Y. 2009. Relationship strength in service industries. International Journal of Marketing Research. 51 (5), $659-685$.

Singh, R. \& Khan, I.A. 2012. An approach to increase customer retention and loyalty in B2C world. International Joumal of Scientific Research Publications 2(6), $1-5$.

Tenenhaus, M,. Vinzi, V.E., Chatelin, Y.M. \& Lauro, C. 2005. PLS path modeling. Computational Statistics \& Data Analysis, 48(1), $159-205$.

Thompson, B. 2005. The loyal connection. Secrets to customer retention and increases profits. CMRguru.com

Tsai, H. T. \& Haung H. C. 2007. Determinants of e-repurchase intentions: An integrative model of quadruple retention drivers. Journal of Information \& Management 4, 231-239.

Van Vureen, T., Roberts-Lombard, M. \& van Tonder, E. 2012. Customer satisfaction, trust and commitment as predictors of consumer loyalty within the optimetric practice environment. Southern African Business Review. 16 (3), 81-96.

Verhoef, P.C. 2003. Understanding the effects of customer relationship: Management efforts on customer retention and customer share development. Journal of Marketing. 67 (3) 30-45.

Vesel, P. \& Zabkar, V. 2009. Managing customer loyalty through the mediating role of satisfaction in the DIY retail royalty programme. Journal of Retailing and Customer Services. 16 (1), 396-406.

Villanueve, J. \& Hanssens, D.M. 2007. "Customer equity: Measurement, management and research opportunities". Foundations and Trends in Marketing. 1 (1), 1-95.

Volkora, N. 2008. Determinants of retail revenue in today's airports. Berlin: GAP

Wagner-Tsukamot, S \& Tadajewsla, M. 2006. Cognitive anthropology and the problem solving behaviour of green consumers. The Journal of Consumer Behaviour 175(1), 235-244

Wahab, S. \& Norizan, N.S. 2012. The influence of service recovery stratergies on the word of mouth: Views of mobile phone users. International journal of Computer science. 9 (3), 99-108.

Westhuizen, C.V. \& Kok, J.A. 2006. Intellectual capital management in South African retail company. South African Journal of information management 8 (4), 1-15.

Wetzels M., Odekerken-Schröder, G. \& Van Oppen, C. 2009. Using PLS path modeling for assessing hierarchical construct models: guidelines and empirical illustration. Management Information Systems Quarterly, 33(1), 177-195.

Wilson, M. 2003. South African retail industry. Httt: www.ey.co.za. Date of access 20 Aug 2013.

Yang, Z. \& Peterson, R.T. 2004. Consumer perceived value, satisfaction and loyalty: The role os wsitching costs. Psychology and Marketing. 21 (10). $799-$ 822.

Yi, Y. \& La, S. 2004. What influences the relationship between customer satisfaction and repurchase intention. Investigating the effects of adjusted expectations and loyalty. Psychology Marketing 21 (5) 351-373.

Zhang, C. \& Pan, F. 2009. The impacts of customer satisfaction on profitability. A case study of state-owned enterprises in China. Xiamen University 1(1).

Zhang, Y., Fang, Y., Wei, K.K., Ramsey, E., McCole, P. \& Chen, H. 2011. Repurchase intention in B2C e-commerce-a relationship quality perspective. Information Management 48(6):192-200. 